\title{
Pod Morphology of Leguminous Host Plants and its Influence on Ovipositional Preference of Callosobruchus chinensis (L.)
}

\author{
Abhilasa Kousik Borthakur ${ }^{1 *}$, Inee Gogoi ${ }^{2}$, Dilip Kr. Saikia ${ }^{2}$, \\ Palash Deb Nath ${ }^{3}$ and Hemanta Saikia ${ }^{4}$
}

\author{
${ }^{1}$ Krishi Vigyan Kendra, Assam Agricultural University, Darrang-784125, India \\ ${ }^{2}$ Department of Entomology, ${ }^{3}$ Department of Plant Pathology, ${ }^{4}$ Department of Agricultural \\ Statistics, Assam Agricultural University, Jorhat-785013, India
}

*Corresponding author

\author{
A B S T R A C T
}

\begin{tabular}{|l|}
\hline Ke y w o r d s \\
$\begin{array}{l}\text { Callosobruchus } \\
\text { chinensis, Pulses, } \\
\text { trichome, } \\
\text { Ovipositional } \\
\text { parameters, } \\
\text { Correlation }\end{array}$ \\
\hline Article Info \\
\hline $\begin{array}{l}\text { Accepted: } \\
15 \text { August } 2020 \\
\text { Available Online: } \\
\text { 10 September } 2020\end{array}$ \\
\hline
\end{tabular}

An experiment was conducted to study the influence of physical characters of pods on ovipositional preference of Callosobruchus chinensis (L.) under laboratory conditions. The data on physical characters of pods revealed that pod length was maximum in cowpea $(14.13 \mathrm{~cm})$ and minimum in chickpea pods $(2.38 \mathrm{~cm})$. Cowpea pods had the maximum number of trichomes $\left(14.16 / \mathrm{mm}^{2}\right)$ followed by chickpea $\left(8.16 / \mathrm{mm}^{2}\right)$, black gram $\left(6.66 / \mathrm{mm}^{2}\right)$ and green gram $\left(4.16 / \mathrm{mm}^{2}\right)$. Pod wall thickness was highest in cowpea pods $(0.73 \mathrm{~mm})$ followed by black gram pods $(0.58 \mathrm{~mm})$. Pod wall thickness of green gram and chickpea pods was same i.e. $0.51 \mathrm{~mm}$. Correlation analysis between ovipositional parameters of Callosobruchus chinensis (L.) and morphological parameters of pods revealed that eggs laid, hatchability percentage and adult emergence had a negative correlation with trichomes number $/ \mathrm{mm}^{2}$ and pod wall thickness, whereas pod length showed a positive correlation with eggs laid, hatchability percentage and adult emergence percentage.

\section{Introduction}

Pulses are an integral source of nutrition throughout the world. Apart from serving as an excellent source of protein, they also enrich the soil quality by its unique properties like biological nitrogen fixation. Green gram is one such pulse which is enriched with the goodness of health. It contains high level of thiamine which renders it suitable to treat beriberi disease. Green gram being a leguminous crop is used as a green manure crop for enhancing the soil quality. According to the reports of Indian Council of Medical Research (ICMR), green gram contains 25\% protein. Green gram, the third most important pulse crop in the country was cultivated in an area of 9.53 million hectare in the year 201617 and yielded a whopping production of 2.07 million tonnes (Anon., 2016a).Black gram, Vigna mungo (L.) is another outstanding pulse crop which is suitable for dryland agriculture and suits well as an intercrop. Apart from the nutritional benefits, black gram is also a 
nutritive green fodder crop. Black gram is rich in its nutritive amount with $24 \%$ protein, $59.6 \%$ carbohydrates and $1.4 \%$ fat. It is also a rich source of calcium, phosphorus and iron. During the year 2016-17, black gram accounted for an area of 4.49 million hectare and its production was 2.92 million tonnes (Anon., 2016b). Cowpea, Vigna unguiculata (L.) is a multipurpose legume, it can be used a pulse, as a vegetable and also as fodder. Another potential pulse crop is Chickpea. Chickpea when grown in rotation with cereals acts as a good "break" crop to different diseases and pest (Kirkegaard et al., 2008). It is highly nutritive pulse crop containing 38$59 \%$ carbohydrate and 25.3-28.9 protein (Hulse, 1991). In India it is cultivated in an area of 9.53 million hectare and the total production was 9.07 million tonnes (Anon., 2016c).

Pulse crop is vulnerable to insect infestation both in field and storage and it has been found that more than 150 species of insect pest can attack the crop. Among the insect pest of pulses, the family bruchidae is the most destructive one. Except in Antarctica, bruchids are found throughout the world, mostly in the tropical regions of Asia, Africa and South America (Southgate, 1979). In India 117 species of bruchids have been reported which belong to 11 genera and out of these, Callosobruchus is very prominent with regard to its incidence (Hill, 1990). Among these Callosobruchus chinensis is the most destructive (Gowda and Kaul, 1982). C. chinensis is a cosmopolitan pest, it starts its infestation from the field and this primary infestation is carried over to the storage houses resulting in the loss of both nutritional value and economic worth (Gujar and Yadav, 1978).

In order to bring out an appropriate pest management strategy a sheer knowledge of pod morphology is essential. As the pest lays its eggs on the host plant pods in field condition, an effort was taken to study the pod morphology and understand its role on ovipositional preference of Callosobruchus chinensis (L.).

\section{Materials and Methods}

The experiment was conducted at the Department of Entomology, Assam Agricultural University, Jorhat in Assam, India. Green gram (variety-Pratap), black gram (variety-KU301), cowpea (varietyGreen fall) and chickpea (variety-JG16) were used as host plants under CRD with six replications. These plants were grown in pots of $1 \mathrm{~kg}$ capacity and all other agronomic practices were followed to raise the crop. Pesticide use was totally restricted. After pod formation, 4 mature pods were selected from each replication and enclosed by a cloth bag. A single pair of 0-24hour old adult beetle was released inside each of the cloth bags which enclosed the pods. Observation on egg laying was recorded upto 5days and the beetles were removed thereafter. Data on number of trichomes per unit area $\left(\mathrm{mm}^{2}\right)$ of the pod was recorded under a binocular microscope (Patel, 2014a). Pod length was measured in centimeter with the help of a digital vernier calipers (Moudgal et al., 2007) and the pod wall thickness was measured in millimeter with the help of a digital vernier caliper (Patel, 2014b). The data was analyzed using SPSS-16 software.

\section{Results and Discussion}

Morphological parameters of the pods of different host plants of Callosobruchus chinensis (L.)

Pod length ranged from $2.38 \mathrm{~cm}$ to $14.13 \mathrm{~cm}$ and significant difference was seen among the four host plants. Cowpea pods had the maximum length $(14.13 \mathrm{~cm})$ followed by 
green gram pod $(8.58 \mathrm{~cm})$. Somya (2015) also reported that the pod length of green gram ranged from $6.2-9.1 \mathrm{~cm}$. Chickpea pods were the shortest of all with a length of $2.38 \mathrm{~cm}$ and in black gram pods the mean pod length was $5.01 \mathrm{~cm}$. Halder and Srinivasan (2011a) also found the pod length of cowpea to be 12.93$15.55 \mathrm{~cm}$.

A significant difference in the number of trichomes $/ \mathrm{mm}^{2}$ among the four host plants was observed. Cowpea pods had the maximum number of trichomes $\left(14.16 / \mathrm{mm}^{2}\right)$ and green gram had the minimum number of trichome on its pod surface $\left(4.16 / \mathrm{mm}^{2}\right)$ which conforns to the results of (Patel, 2014c) who found 3.57 to 3.97 number of trichomes $/ \mathrm{mm}^{2}$. The number of trichome on chickpea and black gram pods were $8.16 / \mathrm{mm}^{2}$ and $6.66 / \mathrm{mm}^{2}$ respectively, which conforms to the results of (Giga et al., 2008). Pod texture was visually observed and it was seen that green gram and cowpea pods were slightly rough while black gram pods were rough in their texture. The pods of chickpea were smooth in their texture.

A significant difference in the pod wall thickness was seen among the four host plants. Maximum pod wall thickness was exhibited by cowpea pods $(0.73 \mathrm{~mm})$ which matches with the results of (Halder and Srinivasan, 2011b). Pod wall thickness of black gram pods was found to be $(0.58 \mathrm{~mm})$. The pod wall thickness of green gram and chickpea pods was same i.e. $0.51 \mathrm{~mm}$ which conforms to the findings of (Patel, 2014d) and (Sallmath et al., 2008a) respectively (Fig. 1 and Table 1).

Table.1 Morphological parameters of the pods of different host plants of Callosobruchus chinensis (L.)

\begin{tabular}{|l|c|c|c|c|c|}
\hline \multicolumn{1}{|c|}{ Treatments } & $\begin{array}{c}\text { Pod length } \\
(\mathbf{c m})\end{array}$ & $\begin{array}{c}\text { Trichome } \\
\text { number/mm }\end{array}$ & $\begin{array}{c}\text { Pod wall } \\
\text { thickness(mm) }\end{array}$ & Pod texture & $\begin{array}{c}\text { Number of eggs } \\
\text { laid / 4 pods }\end{array}$ \\
\hline Greengram & 8.58 & 4.16 & 0.51 & $\begin{array}{c}\text { Moderately } \\
\text { rough }\end{array}$ & 17.50 \\
\hline Blackgram & 5.01 & 6.66 & 0.58 & Rough & 8.50 \\
\hline Chickpea & 2.38 & 8.16 & 0.51 & Smooth & 14.33 \\
\hline Cowpea & 14.13 & 14.16 & 0.73 & $\begin{array}{c}\text { Moderately } \\
\text { rough }\end{array}$ & 11.50 \\
\hline S.Ed $(\mathbf{\pm})$ & 0.34 & 0.57 & 0.02 & & 1.22 \\
\hline CD $(\mathbf{P = 0 . 0 5 )}$ & 0.72 & 1.19 & 0.05 & & 2.55 \\
\hline
\end{tabular}

Data are mean of 6 replications each with 4 pods

Table.2 Correlation coefficient (r) and regression equation of ovipositional parameters with morphological characters of pods of green gram

\begin{tabular}{|l|c|c|c|}
\hline \multicolumn{1}{|c|}{$\begin{array}{c}\text { Ovipositional } \\
\text { parameters }\end{array}$} & Trichome/mm & Pod length (cm) & Pod wall thickness(mm) \\
\hline Eggs laid & $\begin{array}{c}-0.878 * * \\
\mathrm{Y}=-2.7 \mathrm{x}+27.4\end{array}$ & $0.121^{\mathrm{NS}}$ & $-0.098^{\mathrm{NS}}$ \\
\hline Hatching percentage & $-0.400^{\mathrm{NS}}$ & $0.235^{\mathrm{NS}}$ & $-0.544^{\mathrm{NS}}$ \\
\hline Adult emergence & $-0.333^{\mathrm{NS}}$ & $0.186^{\mathrm{NS}}$ & $-0.475^{\mathrm{NS}}$ \\
\hline
\end{tabular}

** Significant at $1 \%$ level of significance 
Table.3 Correlation coefficient (r) of ovipositional parameters with morphological characters of pods of black gram

\begin{tabular}{|l|c|c|c|}
\hline \multicolumn{1}{|c|}{$\begin{array}{c}\text { Ovipositional } \\
\text { parameters }\end{array}$} & Trichome/mm & Pod length(cm) & Pod wall thickness(mm) \\
\hline Eggs laid & $-0.566^{\mathrm{NS}}$ & $0.400^{\mathrm{NS}}$ & $-0.462^{\mathrm{NS}}$ \\
\hline Hatching percentage & $-0.401^{\mathrm{NS}}$ & $0.057^{\mathrm{NS}}$ & $-0.004^{\mathrm{NS}}$ \\
\hline Adult emergence & $-0.353^{\mathrm{NS}}$ & $0.546^{\mathrm{NS}}$ & $-0.204^{\mathrm{NS}}$ \\
\hline
\end{tabular}

Table.4 Correlation coefficient (r) and regression equation of ovipositional parameters with morphological characters of pods of chickpea

\begin{tabular}{|l|c|c|c|}
\hline Ovipositional parameters & Trichome/mm & Pod length(cm) & Pod wall thickness(mm) \\
\hline Eggs laid & $-0.492^{\mathrm{NS}}$ & $0.720^{\mathbf{N S}}$ & $-0.444^{\mathrm{NS}}$ \\
\hline Hatching percentage & $-0.091^{\mathrm{NS}}$ & $0.186^{\mathrm{NS}}$ & $-0.623^{\mathrm{NS}}$ \\
\hline Adult emergence & $-0.340^{\mathrm{NS}}$ & $0.194^{\mathrm{NS}}$ & $-0.686^{\mathrm{NS}}$ \\
\hline
\end{tabular}

Table.5 Correlation coefficient (r) and regression equation of ovipositional parameters with morphological characters of pods of cowpea

\begin{tabular}{|l|c|c|c|}
\hline \multicolumn{1}{|c|}{ Ovipositional parameters } & Trichome/mm & Pod length(cm) & Pod wall thickness(mm) \\
\hline Eggs laid & $-0.355^{\text {NS }}$ & $0.329^{\text {NS }}$ & $-0.485^{\text {NS }}$ \\
\hline Hatching percentage & $-0.520^{\text {NS }}$ & $0.448^{\text {NS }}$ & $-0.022^{\text {NS }}$ \\
\hline Adult emergence & $-0.250^{\text {NS }}$ & $0.091^{\text {NS }}$ & $-0.377^{\text {NS }}$ \\
\hline
\end{tabular}

Fig.1 Regression curve for eggs laid and trichome/mm ${ }^{2}$ in green gram

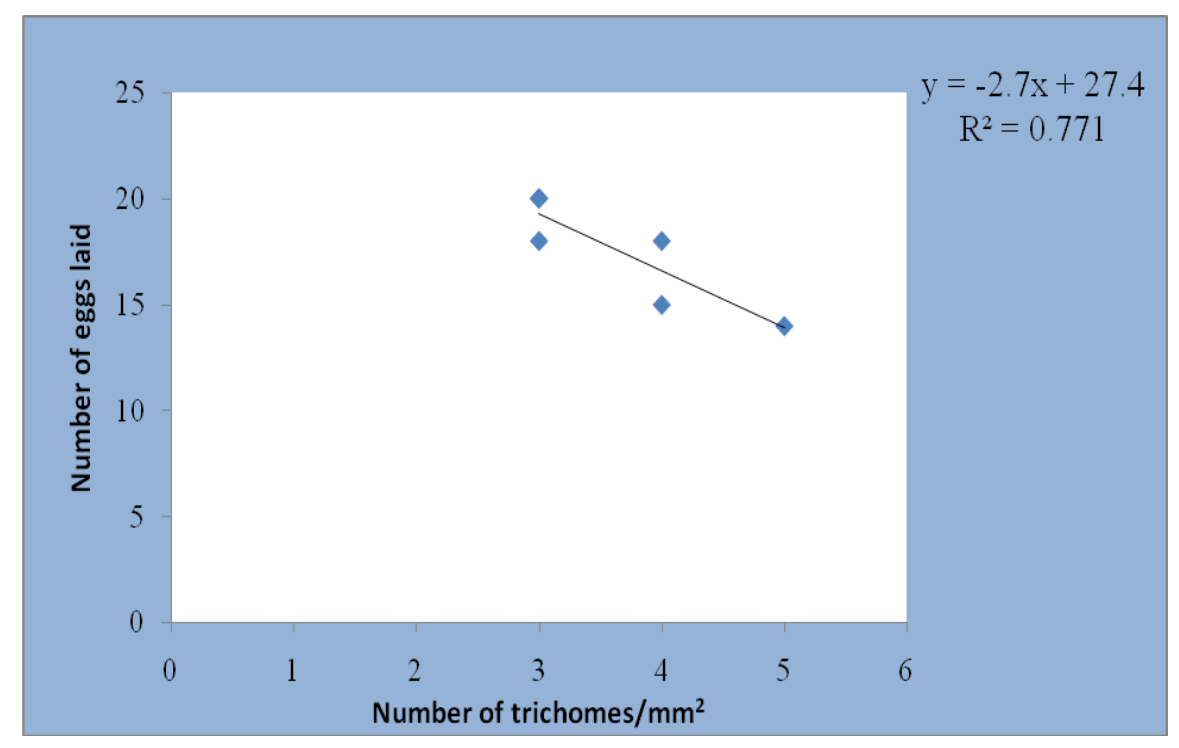


Correlation studies between ovipositional parameters and morphological parameters

Correlation analysis between ovipositional parameters and morphological parameters of pods revealed that eggs laid, hatchability percentage and adult emergence had a negative correlation with trichomes number $/ \mathrm{mm}^{2}$ and pod wall thickness, whereas pod length showed a positive correlation with eggs laid, hatchability percentage and adult emergence percentage. Eggs laid by $C$. chinensis (L.) on green gram pods had a significantly high negative correlation with trichomes $/ \mathrm{mm}^{2} \quad(\mathrm{r}=-0.878)$. Thus highest number of eggs laid on green gram pods may be due to the less number of trichomes present on the pods. The results are in conformity with (Talekar and Linn, 1981) who reported that hairiness of the pods in the 2011 accession of green gram is the reason that $C$. chinensis (L.) laid fewer eggs on the pods of green gram. (Halder and Srinivasan, 2011c) also reported that the highly susceptible variety of cowpea to Maruca vitrata had the least number of trichomes and the lowest pod wall thickness, while it had the highest pod length. (Gandhi et al., 2019) also found that pod length had a positive correlation to bruchid damage in pigeon pea. Pod length has a positive correlation with pod fly infestation (Veda et al., 1975). (Kitch et al., 1991) also reported that pod wall thickness play a major role in pod resistance to $C$. maculates (F.) in cowpea. (Patel, 2014e) also found that pod wall thickness and trichome density had significant negative correlation with the Maruca vitrata population and pod damage. (Sallmath et al., $2008 b)$ reported that chickpea genotypes with higher trichome density and pod wall thickness has a role in imparting resistance or tolerance against chickpea pod borer, Helicoverpa armigera and found a negative correlation with pod damage. (Moudgal et al.,
2007) also found that pod wall thickness and trichome density were negatively correlated to pod fly infestation. He also found a positive correlation between pod length and pod damage which are in conformity to the results of the present investigation (Table 2-5).

In conclusion from the present investigation it is seen that morphological characters of pods do interfere with oviposition by $C$. chinensis (L.). It is seen that trichomes and pod wall thickness act as a barrier in insect oviposition and thus further studies on trichome exudates should be done so that their role in ovipositional behavior can be understood and also determine if they have any adverse effect on natural enemies. Moreover longer pod length was found to be beneficial for the pest to lay eggs, which may be due to the fact that longer the pods, more the number of seeds inside it. Thus it is very important to study the morphological and biochemical basis of resistance in host plants in order to develop resistant varieties against bruchid attack for an effective management programme.

\section{Acknowledgements}

I would like to express my sincere gratitude to Dr. Anjumani Devi, Assistant Professor, Department of Entomology, Assam Agricultural University for her guidance and support throughout the entire research work.

\section{References}

Annonymous, 2016. Annual report, Directorate of pulses development. Ministry of agriculture and farmers welfare.

Gandhi, B. K.; Bandi, S. M.; Satheesh Naik, S. J.; Singh, S. K. and Kumar, K. 2019. Character association and assessment of yield loss in pigeonpea cultivars infested by pod fly and bruchid. Legume Research: An International Journal. 42(3): 1-5.

Gowda, C.L. L. and Kaul, A. K. 1982.Pulses in 
Bangladesh. Bangladesh Agriculture Research Institute, Joydebpur and Food and Agricultural Organization of United Nations. pp. 55-80.

Gujar, G. K. and Yadav, T. D. 1978. Feeding of Callosobruchus maculatus (F.) and Callosobruchus chinensis (L.) in greengram.Indian Journal of Entomology. 40(2): 108-112.

Halder, J. and Srinivasan, S. 2011. Varietal screening and role of morphological factors on distribution and abundance of spotted pod borer, Maruca vitrata (Geyer) on cowpea. Plant Protection Science. 19(1):71-74.

Hill, D.S. 1990. Pests of stored product and their control. 1st edition, Cambridge University press, London. p. 780.

Hulse, J. H. 1991. Uses of Tropical Legumes: Proceedings of a Consultants' Meeting. ICRISAT Center, ICRISAT, Patancheru, AP, 502(324): 11-27.

Kirkegaard, J.; Christen, O.; Krupinsky, J. and Layzell, D. 2008. Break crop benefits in temperate wheat production. Field Crops Research. 107(3): 85-195.

Kitch, L. W.; Shade, R. E. and Murdock, L. L. 1991. Resistance to the cowpea weevil (Callosobruchus maculatus) larva in pods of cowpea (Vigna unguiculata). Entomologia experimentalis et applicata, 60(2), 183-192.

Moudgal, R.K.; Lakra R. K.; Dahiya, B. and Dhillon, M.K. 2007. Physico-chemical traits of Cajanus cajan (L.) Millsp. pod wall affecting Melanagromyza obtusa (Malloch) damage. Euphytica. 161: 429436.

Patel, H. C. 2014. Life table and management of spotted pod borer, Maruca vitrata (Geyer) in green gram, Vigna radiata (Linnaeus) Wilczek. Doctoral dissertation, Anand Agricultural University, Anand.

Sallmath, P. M.; Patil, S. A.; Gowda, C. L. L. and Sharma, H. C. 2008. Biophysical and biochemical basis of host plant resistance to pod borer (Helicoverpa armigera Hubner) in chickpea (Cicer arietinum L.). Indian Journal of Genetics and Plant Breeding. 68(3): 320-323.

Sowmya, T. 2015. Studies on characterization and seed storability against pulse beetle (Callosobruchus chinensis) in green gram genotypes. Doctoral dissertation, Professor Jayashankar Telangana State Agricultural University. Hyderabad

Talekar, N. S. and Hwa Lin, Y. 1981. Two sources with differing modes of resistance to Callosobruchus chinensis in mungbean. Journal of Economic Entomology. 74(5): 639-642.

Veda, O.P.; Purohit, M.L. and Sood, N.K. 1975.Varietal susceptibility of 'arhar' Cajanus cajan (L.) Millsp. to Melanagromyza obtusa Mall., Exalastis atomosa Wlsm and Heliothis armigera Hb. Jawaharlal Nehru Krishi Vishwa Vidyalaya Research Journal.9(1/2): 7-9.

\section{How to cite this article:}

Abhilasa Kousik Borthakur, Inee Gogoi, Dilip Kr. Saikia, Palash Deb Nath and Hemanta Saikia. 2020. Pod Morphology of Leguminous Host Plants and its Influence on Ovipositional Preference of Callosobruchus chinensis (L.). Int.J.Curr.Microbiol.App.Sci. 9(09): 1888-1893. doi: https://doi.org/10.20546/ijcmas.2020.909.238 